\title{
FORESTS AND CLIMATE CHANGE IN CZECHIA: AN APPEAL TO RESPONSIBILITY
}

\author{
JOSEF FANTA, PETR PETŘíK \\ Institute of Botany, The Czech Academy of Sciences, CZ-252 43 Prìhonice \\ Corresponding authorse-mails: jfanta.cz@gmail.com; petrik@ibot.cas.cz
}

Received: $24^{\text {th }}$ October 2018 , Accepted: $2^{\text {nd }}$ January 2019

\begin{abstract}
Forests cover more than one third of the area of Czechia and provide many environmental, economic, social and cultural benefits. Only a small part of the country's forested area is left to nature. Most Czech forests are managed, with Norway spruce as the main tree species. The ongoing climate change progressively creates new conditions for the functioning of forests as important components of the landscape and providers of ecosystem services for society. Until recently, Czech forestry policy makers had not paid enough attention to climate change. As a result, Czech forests grapple with increasing instability caused by repeated windstorms, droughts and insect plagues. Traditionally applied management methods and rigid business models are not suitable for resolving the situation. Czech forestry thus takes an exceptional position within Europe. The responsibility for the development of the adaptation strategy and sustainable management policy lies in the hands of forestry policy makers. In order to restore stability and to ensure multifunctionality of forests under new climatic conditions, it will be necessary to introduce a new model of forest management. Compared to the traditional forestry model based on age classes, the new management model must be more flexible and better adapted to the new environmental situation. The principles of the new forestry policy should stem from agreement and cooperation of the forestry sector with scientific and nature protection institutions, as well as from an active discussion within society.

The starting point of the change are the documents Strategy of Adaptation to Climate Change under the Conditions of the Czech Republic and National Action Plan, elaborated in 2016 and 2017 by the Ministry of the Environment, and the Strategic Framework Czech Republic, approved by the Czech government. The chosen adaptation strategy and its implementation must not only restore the stability of forests, but also improve the future position of the Czech forestry sector among European countries.

Keywords: Czech forestry; climate change impact on forests; adaptation strategy; forest management innovation; new forestry policy concept; biodiversity; Platform for the Landscape
\end{abstract}

\section{INTRODUCTION}

Forests cover nearly one third of the Czech landscape and affect its environment in a considerable way. Their good state and functioning are the basic preconditions for the provision of optimal ecosystem services to society. As an independent site factor, the climate affects forest ecosystems, which, in turn, moderate local and regional microclimates, soils 
and water regimes over large areas. Conversely, forest management creates conditions supporting the production function of forests. These mutual relationships have various consequences not only for forests, but for entire landscapes.

The ongoing climate change has a strong impact on forests. Increasing temperatures, more frequent droughts and extreme climatic fluctuations form the background of disturbances and insect plagues that afflict Czech forestry, alter the biodiversity of forests and bring uncertainties as to the future provision of forest services and the benefits of forests for mankind, including wood production (Fanta, 1992; Moldan ed., 1993; Buček \& Vlčková, 2009 a, b; Hlásny et al., 2012). Only some $11 \%$ of Norway spruce forests are growing on natural sites. Most Czech forests are monocultures of Norway spruce planted and growing in unsuitable conditions outside of the species' natural niche. Such commercial forests are highly vulnerable to the new climatic conditions. To minimize the risks, forest management must adapt to the changes. Unlike in neighbouring countries, leading policy-makers of the Czech forestry sector have not reacted to the new situation in time. Instead, they have continued to prefer traditional management methods, which are oriented mainly towards the production of timber and other wood.

Forest management was established in the $18^{\text {th }}$ and $19^{\text {th }}$ centuries as a set of technical operations aimed to maximize wood production, which was indispensable for industrial development at the time (Silvicultura Oeconomica, von Carlowitz, 1713). The so-called age-classes forestry approach (Hartig, 1791; Hundeshagen, 1827) combined all temporal and economic aspects in a model corresponding with the ideology of economic growth of the Second Industrial Revolution in the best way. This approach, however, completely ignored natural conditions. This has harmed the forestry sector not only ecologically, but also economically. The development of ecology as a science and attempts to apply ecological knowledge in forest management, although successful (e.g. Gayer, 1886; Möller, 1922; Konšel, 1931), did not change the official concept of forestry policy of that time. Forests of today are ecologically unstable products of previous forestry policy and forest management. To minimize future risks, a new forestry policy and a proper corresponding forest management concept must be developed.

\section{FORESTRY AND CLIMATE CHANGE ACTIONS IN EUROPE}

In the founder countries of the EU, foresters have been paying attention to climate change and its impact on forests and forestry since the beginning of the international discussion headed by the Intergovernmental Panel on Climate Change (IPCC, 2014) and later, with declining biodiversity also by the Intergovernmental Science-Policy Panel on Biodiversity and Ecosystem Services (IPBES, 2018). In some countries, working teams have been established already in the 1990s, to investigate various aspects of the problem and to identify strong and weak points of the matter (Fanta, 1992). Climate change has become one of the most important research topics of the European Forest Institute and, to date, hundreds of scientific publications have appeared in scientific journals worldwide. The complicated nature of the matter has stimulated broad international communication among specialists from different parts of Europe (e.g. Bolte et al., 2009; Lindner et al., 2010; Hanewinkel et al., 2012; de Frenne et al., 2013; Fitzgerald \& Lindner, 2013; Wagner et al., 2014; and Nabuurs in this issue), especially in the fields of climatology, biology, pedology and ecology, and brought them together with foresters to find answers to both scientific and practical questions connected with climate change. Moreover, respected international organizations such as the European Environment Agency, the Food and the Agricultural Organization, the International Union of Forest Research Organizations and European Academies' Science 
Advisory Council are participating in this process, discussing topics such as short rotation forestry and accounting procedures used in the LULUCF sector. Last but not least, the two main forest management certification organizations, the Forest Stewardship Council (FSC) and the Programme for the Endorsement of Forest Certification (PEFC), saw an increase in the area of certified forests; however, the percentage of the total forest area covered by such forests is still low (http://web.unep.org). Because of the aforesaid strange attitude of the Czech forestry policy-makers, hardly any Czech foresters were involved in these international research and policy programmes.

\section{IMPACT OF CLIMATE CHANGE ON FORESTS: LESSONS FROM THE PAST CENTURIES}

The present climate change is not the first to occur in Central Europe. The results of palaeoecological investigations concerning changes in forests and vegetation development over the Holocene in Central Europe are a good basis for imagining the course of changes we will be confronted with in forests and vegetation under the current climate (e. g. Firbas, 1949, 1952; Ložek, 1973; Holten, 1990; Jankovská \& Pokorný, 2008; Pokorný, 2013). In most cases, the changes were rather rapid and not reverting, leading to the development of new types of vegetation cover or to the shifting of vegetation zones (see Machar, et al. in this issue). In the historical period, the changes in vegetation cover have been concurrent with human activities in the landscape. For example, the warm climate in the first half of the Middle Ages (in the $9^{\text {th }}$ and $13^{\text {th }}$ centuries) facilitated the colonization of lowland areas of Northern and Northwestern Europe, accompanied by extensive deforestation and the development of large areas of wind-blown sand landscapes in today's Flanders, in the Netherlands, northern Germany and northern Poland, which nearly ended in desertification (Koster, 1978; 2010). The colonization of uplands and low mountains, accompanied by extensive deforestation in the Czech lands, formed the basis of prosperity of the Bohemian kingdom in the $13^{\text {th }}$ and $14^{\text {th }}$ centuries. However, a rapid swing in the opposite direction - the cool and wet period of Little Ice Age (in the $15^{\text {th }}-19^{\text {th }}$ centuries) - caused the abandonment of many settlements in hilly areas and led to the cessation of agricultural land use of upland areas. This development was followed by extensive soil erosion of abandoned agricultural land. As a result, the $14^{\text {th }}$ century has been identified as the period of greatest displacements of soil matter in the history of the Central-European Quaternary (Bork et al., 1998).

At the end of the $17^{\text {th }}$ century, Central Europe had the lowest forest cover in its history. It was a crisis which developed as a result of former extensive clearing of previously unmanaged forests. The inception of organized forestry (von Carlowitz, 1713), in reaction to this new situation, made it possible to resolve the first Central-European energy crisis, which was caused by a lack of firewood and timber - the basic energy and construction materials of the time. The cool and wet Little Ice Age was a favourable period for the development of coniferous forests. Organized forest management had made it possible not only to restore cleared forests, but also to afforest abandoned agricultural land, and, in the following centuries (i.e. the first industrial period), to produce previously unheard of quantities of firewood and timber. Unfortunately, this was achieved by the establishment of monoculture plantations, at the expense of natural conditions. What is even worse is that the age-classes forestry model developed at that time survives virtually unchanged to this day.

The aforesaid examples show that the impact of climate change on forests will potentially be great. Moreover, the speed of the ongoing change confirms the knowledge gained by the palaeoecological research. 


\section{Current Situation in CZechia}

In contrast to other European countries, the leading bodies of the Czech forestry sector had until recently (January 2019) not taken any clear position on the matter of climate change. This has several causes. The first reason stems from the discontinuity in the political development of the country since the half of the past century (Petrík et al., 2015). In that period, the totalitarian regime was not interested in environmental issues and blocked any rational discussion in this field. This was logical. The second half of the $20^{\text {th }}$ century was a period that left heavy environmental damage to forests from industrial pollution (Hruška \& Cienciala, 2001; 2003). However, the chaotic political situation after the Velvet Revolution in November 1989 had a similar effect. Initial attempts to change the course for the better, such as the Conference on European Environment (held in Dobř́š in 1991; Moldan, 1993), were successful, but they did not gain sufficient attention. The political mood was geared above all towards economic aspects, at the expense of the environment. Under the influence of this approach, for example, the main Czech forestry organization (the Czech State Forest Service) decided to outsource all field operations (such as tending, felling and reforestation), and to largely limit its own activities on administrative tasks, with economic aspects at the forefront. The ecological aspects of forest management were sidelined. Hardly any attention was paid to the potential danger and prevention of windbreaks, and even the effects of the Kyrill storm in 2007 did not bring any change in approach.

A new impulse came with the accession of the country to the European Union. The National Forestry Program II (2008-2013) explicitly addressed all important topics pertaining to the impact of climate change on forests and forestry. However, because of an unstable political situation at the time, the reality fell flat. Forest diebacks of Norway spruce forests in some parts of the country, caused by drought, root rot or bark beetles, have already reached dimension on which they are hard to address within the regular forest management scheme. Several climate-change-oriented publications (e.g. Buček \& Vlčková, 2009a, b; Hlásny, 2012) were published but did not find immediate continuation and support in institutional research programmes or in forestry practice. Not even the Principles of the state forestry policy, accepted in 2012 by the Czech government, mentioned the need for change in the approach to forests and forestry under threat from climate change. In the meantime, however, the technical means for tackling bark beetle outbreaks turned out to be ineffective and the outbreak became a calamity. In 2017 a state of emergency was declared in three Moravian provinces. One year later, clearings covered an area of 40,000 hectares, and other areas are exposed to the same danger. It is clear that the present concept of forestry and forestry policy has failed spectacularly.

\section{FUTURE CLIMATE AND ITS POTENTIAL IMPACT ON FORESTS AND FORESTRY}

The current climate change will affect not only the nature of forests as ecosystems and vegetation formations, but also the quantity and quality of benefits and services they provide, which contemporary society cannot do without. Certain processes, including some that are invisible, are already under way, and others can be expected to start taking place sooner or later. Examples of such processes are numerous. Many of them have already been investigated in other countries, for example Slovenia, Austria, Germany and Switzerland.

Several examples:

- Change in the course of ongoing temperatures and precipitation, their distribution during the year and potential extreme fluctuations (droughts and floods; e.g. Bässler, 2008; Pretel, 2009; Remund et al., 2016). 
- Changes in the tree species composition of managed forests (strong impact on Norway spruce forests growing on unsuitable sites; regional differences related to site conditions (e.g. Leuzinger et al., 2005; Hlásny, 2012; Lévesque et al., 2013).

- Latitudinal and elevational shifts in the distribution of forest communities and their transformation are predicted (e.g. Buček \& Vlčková, 2009a, b; Brus et al., 2011; Zimmermann, 2013; Machar et al. in this issue).

- Stimulation and suppression of soil processes in some areas and on sensitive sites (abundant nitrogen release and rapid growth stimulation of Norway spruce; growth restriction of vegetation and trees on dry sites; e.g. Rothe et. al., 1998; Rothe \& Mellert, 2004).

- Changes in ecological tolerance of tree species, forest growth and biomass production biomass reduction at lower elevations due to drought; greater wood production in mixed forests compared to monocultures (e.g. Lafond et al., 2014; Pretzsch et al., 2015a); and contemporary excessive growth of Norway spruce and its low ability to resist wind and snow (e.g. Boisvenue \& Running, 2006; Bolte et al., 2010; Braun et al., 2015; Pretzsch et al., 2015b; Bosela et al., 2016).

- Insect outbreaks in forests (bark beetle infestation of Norway spruce plantations at lower elevations and on sensitive sites, see e.g. Engesser et al., 2008; Hlásny \& Turčány, 2009; Př́ihoda \& Lukášová, 2014).

- Changes in the occurrence of saprophytic and saproxylic organisms on forest trees, e.g. Chalara fraxinea on indigenous ash trees; Gemmamyces piceae on the introduced species Picea engelmannii (Loo, 2009; Sturrock et al., 2011; Černý, 2016); root rot on Norway spruce at lower elevations; potential root rot on young Douglas fir trees planted on sites formerly occupied by Norway spruce (Vor et al., 2015; Holderegger et al., 2017); loss of mycorrhizal fungi on trees on some places (e.g. Oliva \& Stenlid, 2012; Desprez-Loustau et al., 2016).

- Changes in natural regeneration of forest trees: the rise and following decline of natural regeneration of Norway spruce on unsuitable sites; increase of natural regeneration of European beech and other broadleaves in lower elevation zones (Ott et al., 1991; Bugmann, 1999; Moser et al., 2015).

- Increased danger of wind- and stormbreaks in Norway spruce monocultures (Schelhaas et al., 2003) and forest fires under dry conditions, especially in the summer period, i.e. during harvesting of agricultural crops.

The mutual relationships of these and other examples of climate change consequences for forest trees and sites create innumerable possibilities of how forest ecosystems will react to climate conditions changing in time and space. In the long term, climate change will alter the conditions for forest growth and the functioning of forests as ecosystems. It will influence local ecosystem services (i.e. production, supporting, regulation and cultural - see the Millenium Ecosystem Assessment, 2005). This will inevitably create vastly different conditions for the management of forests as a renewable natural resource.

The decision on how to properly manage forests under future climatic conditions should be based on basic research knowledge, a modern approach to forestry, practical experience and public awareness.

\section{TRANSITION TO SUSTAINABLE FOREST MANAGEMENT}

Thanks to environmental science, forests are no longer viewed merely as a source of wood, but as ecosystems and irreplaceable structural components of the landscape. The goals of modern forestry are defined in terms of sustainability, multi-functionality, biodiversity and provision of ecosystem services (see e.g. MCPFE/PEBLDS consultation meeting on pan- 
European recommendations for afforestation and reforestation in the context of the UNFCCC). Under these conditions, forest management must be understood as a coordinated activity based on the integration of ecological and economic insight and executed as an integrated process enabling and securing the aforesaid functions and goals. The close-to-nature management model expresses the character of this approach in the best way. The word 'nature' does not mean that technical management interventions should be excluded. Instead, it indicates the respect for the broad context of ecological relationships and processes mentioned above; management interventions should not be carried out as a rigid set of prescribed technical operations; each intervention has to be in line with natural development. Logically, any forest management concept must be adaptive, meaning flexibly adaptable to various situations, closely corresponding to local conditions and aimed towards the achievement of forest management goals.

In fact, such a concept is not new to Central European or even to Czech forestry. Similar concepts of forest management have been developed and applied, both in the past and recently, mostly in response to the dissatisfaction with the old-fashioned age-classes-forestry model (e.g. Rubner, 1968). Some forest owners in Central Europe have decided to apply this management approach as a general strategy - and with good results, even with regard to economy. In Czechia, good examples are provided by Konias (1951) and Košulič (2010). Recently, this approach has been strongly advocated by the organization Pro Silva Europa with its national branches in various countries (see Pro Silva Bohemica in Czechia; Remeš in this issue). Based on broad scientific knowledge and practical experience, leading European forestry bodies and institutions recommend the close-to-nature management model as the best strategy to cope with the uncertainties brought by climate change (e.g. Kolström et al., 2011). An analogous response can be found in presentations from the EASAC (European Academic Science Advisory Council) 'Beyond Wood Conference', held on 23 May 2016 in Brussels.

The crucial point of the adaptation of Czech forestry to the new climatic situation, however, is the need to change the present business model of the Czech State Forest Service. The present concept is explicitly economy-oriented and does not properly respect the ecological conditions of forests. In fact, this discordance is at the roots of the problems of contemporary forestry, including the expanding bark beetle calamity. The business model must be revised and brought into balance with the regionally different ecological conditions of particular forest areas. This balance is the basic precondition for the development and application of sustainable forest management - the only acceptable model for the future, which can bring stability to local forest environments and the forestry sector as a whole. The development of this new concept is the main contemporary task of Czech forestry policy. It is without doubt that the final result of this process must be a new forest bill.

\section{FORESTRY AND BIODIVERSITY CONSERVATION}

In the new concept of forest management, the maintenance and restoration of biodiversity is an important point. Indigenous trees, plants and other organisms provide greater ecological and physical stability of ecosystems than planted monocultures, which are a cause of severe biodiversity degradation. The problem of biodiversity restoration must be addressed systematically and in coordination with nature and landscape protection administrations (Vor et. al., 2015). Foresters may base their practice on information revealed by long-term investigations in national parks, nature reserves and areas left to natural development. Last but not least, this adaptation process must be related to broader landscape circumstances (Hrnčiarová et al., 2009; Fanta \& Petřík, 2014). In principle, two main approaches to the 
conservation or improvement of forest biodiversity are being discussed: (i) the creation of wilderness areas (maintenance of natural processes with minimum intervention; and (ii) sustainable management linking productive and non-productive functions of forests. The former point pertains to species depending on the continuity of the forest cover, dead wood and large trees (i.e. some bryophytes, lichens, fungi, saprophytic beetles, cavity-nesting birds associated with old forests), which are negatively affected by intensive forest management (Gregory et al., 2007; Virkkala et al., 2008; Moning \& Müller, 2009; Scheidegger et al., 2009; Paillet et al., 2010). The latter approach is applicable to the protection of endangered species through management with shorter rotation times in place of high forest systems, such as coppicing with standards (see Konvička et al., 2006; Hédl et al., 2010). In Europe, progress towards sustainable forest management is periodically monitored (see Lindenmayer et al., 2006; and MCPFE). Silvicultural diversification (sometimes called 'polyculture') is recommended for the mitigation of risks to the biodiversity of forests and the ecosystem services they provide (Felton et al., 2010; Gamfeldt et al., 2013; Löhmus \& Runnel, 2014; Hofmeister et al., 2015). Forest certification as applied by the Forest Stewardship Council (FSC) should be preferred because it leads to the application of stronger measures (Elbakidze et al., 2011).

\section{A CHALLENGE FOR CZECH FORESTRY AND LESSONS FROM OTHER COUNTRIES}

The ongoing climate change is a long-term phenomenon; progressively, it will alter our present environment and create an entirely new set of conditions for the existence of forests in this part of the European continent. Some of these changes are already underway, especially on dry lowland sites. In the short term, however, these changes will also take place under different conditions (Vitasse et al., 2012; Moser et al., 2015). Their impact on forest growth and forest management will be both beneficial (e.g. increased biomass production at higher elevations) and adverse (e.g. lower resistance of damaged forests to diseases). Both local and regional differences in forest management will therefore increase. The future principles of forest management must be derived from detailed knowledge of site conditions and processes of natural ecosystem development.

A good example of a creative approach to the formulation of a new concept of forest management and planning is the forest development type model developed in Baden-Wuerttembergia, Germany (von Teuffel \& Krebs, 1999; von Teuffel, 1999) and officially implemented there since 2014. This model comes as an alternative when monocultures and forestry based on age classes fail (Perpeet, 2001). The Czech alternative of this forest management and planning concept (Černý, 2004) was rejected by the leading Czech forest planning authorities and remains limited to national parks and a few experimental plots (e.g. Forest Enterprise of Mendel University in Křtiny).

Despite the fact that timber production will remain one of the primary purpose of majority of forests, it is essential to find harmony between wood production and other ecosystem functions, such as carbon sequestration in vegetation and soil, water retention, maintenance of biodiversity and social functions (see Stachová in this issue). This coherence must be attained in a both economically and ecologically efficient way. This is a task that requires both an intensive cooperation of the forestry sector with the scientific community and intensive intersectoral cooperation between foresters and nature protection authorities. It also requires an effective system of subsidies supporting the adjustment of forestry policy and the creation of legislation that will open the way towards flexible and adaptive forest management respecting the balance among economic, ecological and social conditions. This is the way to restore the stability of forests and to ensure forest ecosystem services - the most 
important obligations of Czech forestry today ( $c f$. Putz \& Redford, 2009; Harvey et al., 2010; Lindenmayer et al., 2012).

The Czech government has revitalized the Governmental Advisory Board for Sustainable Development and, simultaneously, entrusted the Ministry of the Environment to elaborate the Strategy of Adaptation to Climate Change under the Conditions of the Czech Republic (https://www.mzp.cz/cz/zmena_klimatu_adaptacni_strategie) and its follow-up the National Action Plan (https://www.mzp.cz/cz/narodni_akcni_plan_zmena_klimatu). These initiatives are being followed now by analyses of the effects of the changing climate on the development of various aspects of the economy, the environment and public life. The first good examples of an effective cooperation of the forestry sector with researchers in biology are documents dealing with adaptation of forest management to climate change (Hlásny et al., 2016; Čermák et al., 2016). Further steps should be oriented towards a new, more flexible concept of forest site typology, management of tree species and species mixtures, game management and transitioning from even-aged silviculture to selective cutting in multi-age forests, eventually resulting in the introduction of small-scale management into forest law. In Czechia, specific attention must be paid to the execution of management measures including the use of heavy machinery and to the involvement of the forestry sector in countryside development, especially in cooperation with the agricultural sector.

\section{CONCLUDING REMARKS}

From its very beginnings, organized forestry has focused primarily on the provision of firewood and timber in amounts required by the rapidly evolving industry. The development of methods of silviculture, forest protection and wood harvesting has led to massive changes in tree species composition, the introduction of non-native provenances of forest trees and the introduction of a homogeneous structure of forest stands. At the same time, clear-cutting followed by tree planting represented a technically and economically efficient approach to forest management. Developments over the last decades characterized by dramatic Europe-wide damage to forests and growing demands of the society on the multifunctional character of forests have raised the need for changes in the current paradigm of forest management.

In the face of climate change and related changes in forest disturbance regimes, risk-oriented management becomes the key concept for future development. Unstable monocultural forests need to be transformed into stable, uneven-aged and mixed forests. Only such forests will be able to ensure the provision of the desired forest functions, even in cases of local failure of some tree species, be it as a result of the adverse effects of climatic factors or of pests. Such an approach will reduce the risk of sudden destruction of large forested areas and facilitate the desired asynchronous dynamics and ecological stability of forests and forested landscapes. The landscape framework must also be taken into consideration. With respect for natural conditions, valuable open habitats should not be afforested but kept open to support the landscape diversity. With regard to the needs for multifunctional management that supports biodiversity, water retention in the landscape, accumulation of carbon, etc., it is necessary to create a framework for the implementation of a wider spectrum of management alternatives supporting these functions. Forestry policymakers must also take into account the social significance of these functions and implement an effective subsidy policy.

More than ten years ago, specialists in the field of forestry became divided by the publication of a critical standpoint of Czech scientists and professionals devoted to the protection of Czech forests, which called for systemic changes in forestry (Fanta et al., 2006). 
For the forestry sector such a direct approach was not acceptable. Today, it is clear that it was impossible to achieve positive change in the divided forestry community of that time. With the increasing impact of climate change on forests, however, the need to change the concept of forest management became more pressing than before. Therefore, the Forum 2000 conference (2016) aimed to first ascertain the positions of various groups as the starting point of a discussion about the future concept of Czech forestry. The Platform for the Landscape (www.nasekrajina.eu), a new initiative of the Czech scientific community administered by the Institute of Botany of the Czech Academy of Sciences, offers a forum for such a discussion. The Platform for the Landscape aims to give impetus to the process of elaborating a coherent future-oriented national forestry policy that will be based on scientific, economic and social foundations, and on effective intersectoral cooperation. This initiative is in line with the document Strategic Framework Czech Republic 2030 (2017), which formulates, in general terms, the principles of ecosystem management to secure biological diversity and the provision of ecosystem services in Czechia.

\section{ACKNOWLEDGEMENTS}

The activities of the Platform for the Landscape are supported by the project Strategy AV21, programme ROZE. The work on this publication was supported by the long-term conceptual development programme of the Institute of Botany of the Czech Academy of Sciences (RVO 67985939). Authors would like to thank Frederick Rooks for the text proofreading and Petr Maděra for valuable comments.

\section{REFERENCES}

Bässler, C. (2008). Klimawandel - Trends der Lufttemperatur im inneren Bayerischer Wald (Böhmerwald). Silva Gabreta 14(1), 1-18.

Boisvenue, C. \& Running S. W. (2006). Impacts of climate change on natural forest productivity - evidence since the middle of the $20^{\text {th }}$ century. Global Change Biol. 12, 862-882. DOI: 10.1111/j.1365-2486.2006.01134.

Bolte, A., Ammer, C., Madsen, P., Nabuurs, G.-J., Schall, P., Spathelf, P. \& Rock, J. (2009). Adaptive forest management in Central Europe: Climate change impacts, strategies and integrative concept. Scand. J. For. Res. 24, 473-482. DOI: 10.1080/02827580903418224.

Bolte, A., Hilbrig, L., Grundmann, B., Kampf, F., Brunet, J. \& Roloff, A. (2010). Climate change impact on stand structure and competitive interactions in a southern Swedish spruce beech forest. Eur. J. For. Res. 129, 261-276. DOI: 10.1007/s10342-009-0323-1.

Bork, H.-R. et al. (1998). Landschaftsentwicklung in Mitteleuropa. Klett-Perthes, Gotha.

Bosela, M., Štefančík, I., Petráš, R. \& Vacek, S. (2016). The effects of climate warming on the growth of European beech forests depend critically on thinning strategy and site productivity. Agricultural and Forest Meteorology 222, 21-31. DOI: 10.1016/j.agrformet.2016.03.005.

Braun, S., Remund, J. \& Rihm, B. (2015). Indikatoren zur Schätzung des Trockenheitsrisikos in Buchen- und Fichtenwäldern. Schweiz. Zeitschr. Forstwes. 166, 361-371.

Brus, D. J., Hengeveld, G. M., Walvoort, D. J. J., Goedhart, P. W., Heidema, A. H., Nabuurs, G. J. \& Gunia, K. (2011). Statistical mapping of tree species over Europe. Eur. J. For. Res. 131, 145-157. DOI: 10.1007/s10342-011-0513-5. 
Buček, A. \& Vlčková, V. (2009b). Možný vliv globálních změn klimatu na vegetační stupně 1990-2030. Mapy 1: 2,000.000. Atlas krajiny ČR, 7. odd. MŽP - VÚKOZ, Praha.

Buček, A. \& Vlčková, V. (2009a). Scénář změn vegetační stupňovitosti na území České republiky: deset let poté. Ochrana prírody 64, 8-11.

Bugmann, H. (1999). Anthropogene Klimaveränderung. Sukzessionsprozesse und forstwirtschaftliche Optionen. Schweiz. Zeitschr. Forstwes. 150, 275-287.

Čermák, P., Zatloukal, V., Cienciala, E., Pokorný, R. et al. (2016). Katalog lesnických adaptačnich opatření. MENDELU-ČZU-IFER, Praha-Brno.

Černý, K., (2016). Nepůvodní invazní patogeny dřevin - výzva nebo předem ztracený boj? Živa LXIV (CII), 6: 286-291.

Černý, M. (ed.) (2004). Metodika tvorby lesního hospodářského plánu na podkladě provozní inventarizace. IFER, Jílové.

De Frenne, P., Rodríguez-Sánchez, F., Coomes, D. A., Baeten, L., Verstraeten, G., Vellend, M., Bernhardt-Römermann, M., Brown, C. D., Brunet, J., Cornelis, J., Decocq, G. M., Dierschke, H., Eriksson, O., Gilliam, F. S., Hédl, R., Heinken, T., Hermy, M., Hommel, M., Jenkins, M. A., Kelly, D. L., Kirby, K. J., Mitchell, F. J. G., Naaf, T., Newman, M., Peterken, G., Petřík, P., Schultz, J., Sonnier, G., Van Calster, H., Waller, D. M., Walther, G.-R., White, P. S., Woods, K., Wulf, M., Graae, B. J. \& Verheyen, K. (2013). Microclimate moderates plant responses to macroclimate warming. PNAS 110 (46): E18561-E18565. DOI: 10.1073/pnas.1311190110.

Desprez-Loustau, M. L., Aguayo, J., Dutech, C., Hayden, K. J., Husson, C., Jakushkin, B., Marcais, B., Piou, D., Robin, C., Vacher, C. et al. (2016). An evolutionary perspective to address forest pathology challenges of today and tomorrow. Annals For. Sci. 73, 45-67.

Elbakidze M., Angelstam, P., Andersson, K., Nordberg, M. \& Pautov, Y. (2011). How does forest certification contribute to boreal biodiversity conservation? Standards and outcomes in Sweden and NW Russia. Forest Ecol. Manag. 262, 1983-1995. DOI: 10.1016/j.foreco.2011.08.040.

Engesser, R., Forster, B., Meier, F. \& Wermellinger, B. (2008). Forstliche Schadorganismen im Zeichen des Klimawandels. Schweiz. Zeitschr. Forstwes. 159, 344-351.

Fanta, J. (1992). Possible Impact of Climatic Change on Forested Landscapes in Central Europe: A Review. Catena Supplement 22, 133-151.

Fanta, J., Farkač, J., Hruška, J., Košulič, M. sen., Prach, K. \& Rusek, J. (eds.) (2006). Stanovisko vědců a odborných pracovniků kochraně českých lesü. (manuscript, not published).

Fanta, J. \& Petř́k, P. (eds.) (2014). Povodně a sucho: krajina jako základ řešení. Institute of Botany, The Czech Academy of Sciences, Průhonice.

Felton, A. et al. (2010). Replacing coniferous monocultures with mixed-species production stands: An assessment of the potential benefits for forest biodiversity in northern Europe. Forest Ecol. Manag. 260(6), 939-947. DOI: 10.1016/j.foreco.2010.06011.

Firbas, F. (1949, 1952). Spät- und nacheiszeitliche Waldgeschichte Mitteleuropas nördlich der Alpen. Vol. I, II. Fischer, Jena.

Fitzgerald, J. \& Lindner, M. (eds.) (2013). Adapting to climate change in European forests Results of the MOTIVE project. Pensoft Publ., Sofia.

Gamfeldt, L. et al. (2013). Higher levels of multiple ecosystem services are found in forests with more species. Nature Comm. 4, 1340. DOI: 10.1038/ncomms2328. 
Gayer, K. (1886). Der gemischte Wald, seine Begründung und Pflege insbesondere durch Horst- und Gruppenwirtschaft. Berlin.

Gregory, R. D., Vorisek, P., Van Strien, A., Gmelig Meyling, A. W., Jiguet, F., Fornasari, L., Burfield, I. J. (2007). Population trends of widespread woodland birds in Europe. IBIS 149 (Suppl. 2), 78-97. DOI: 10.1111/j.1474-919X.2007.0698.x.

Hanewinkel, M., Cullmann, D. A., Schelhaas, M.-J., Nabuurs, G.-J. \& Zimmermann, N. E. (2012). Climate change may cause severe loss in the economic value of European forest land. Nature Clim. Change, Letters. DOI: 10.1038/NCLIMATE1687.

Hartig, G. L. (1791). Anweisung zur Holzzucht für Förster. Marburg.

Hartl-Meier, C., Dittmar, Ch., Zang, Ch. \& Rothe, A. (2014). Mountain forest growth response to climate in the Northern Limestone Alps. Trees 28, 819-829. DOI: 10.1007/s00468-014-0994-1.

Harvey, C. A., Dickson, B. \& Kormos, C. (2010). Opportunities for achieving biodiversity conservation through REDD. Conserv. Letters 3(1), 53-61. DOI:10:1111/j.1755-263X.2009.00086.x.

Hédl, R., Kopecký, M. \& Komárek, J. (2010). Half a century of succession in a temperate oakwood: from species-rich community to mesic forest. Diversity and Distributions 16, 267-276. DOI: 10.1111/j.1472-4642.2010.00637.x.

Hlásny, T. \& Turčány, M. (2009). Insect pests as climate change driven disturbances in forest ecosystems. In: Strelcova K. et al., eds.: Bioclimatology and Natural Hazards. Springer, Berlin.

Hlásny, T. (2012). Jak může ovlivnit změna klimatu smrkové porosty v ČR? Les. práce 91(1), 29-31.

Hlásny, T., Marušák, R., Novák, J. et al. (2016). Adaptace hospodaření ve smrkových porostech České republiky na změnu klimatu s důrazem na produkci lesa. Lesnický průvodce 15, VÚLHM, Strnady.

Hofmeister, J., Hošek, J., Brabec, M., Dvořák, D., Beran, M., Deckerová, H. et al. (2015). Value of old forest attributes related to cryptogam species richness in temperate forests: A quantitative assessment. Ecol. Indicators 57, 497-504. DOI: 10.1016/j.ecolind.2015.05.015.

Holderegger, R. et al. (2017). Auswirkungen des Douglasienanbaus auf die Biodiversität: wichtige Forschungsfragen (Essay). Schweiz. Zeitschr. Forstwes. 168(1), 21-25.

Holten, J. I. (ed.) (1990). Effects of climate change on terrestrial ecosystems. NINA, Trondheim.

Hrnčiarová, T., Mackovčin, P., Zvara, I. et al. (2009). Atlas krajiny České republiky. MŽP Praha - VÚKOZ Průhonice.

Hruška, J. \& Cienciala, E. (eds.) (2001). Dlouhodobá acidifikace a nutriční degradace lesnich půd - limitujíci faktor současného lesnictví. MŽP, Praha.

Hruška, J. \& Cienciala, E. (eds.) (2003). Long-term acidification and nutrient degradation of forest soils - limiting factors of forestry today. Czech Ministry of the Environment, Prague.

Hundeshagen, J. C. (1827). Lehrbuch der forst- und landwirtschaftlichen Naturkunde. Tübingen.

IPBES (2018). The IPBES regional assessment report on biodiversity and ecosystem services for Europe and Central Asia. Rounsevell, M., Fischer, M., Torre-Marin Rando, A. \& Mader, A. (eds.). Secretariat of the Intergovernmental Science-Policy Platform on Biodiversity and Ecosystem Services, Bonn, Germany. 1-892. 
IPCC (2014). Climate Change 2014: Synthesis Report. Contribution of Working Groups I, II and III to the Fifth Assessment Report of the Intergovernmental Panel on Climate Change [Core Writing Team, R.K. Pachauri and L.A. Meyer (eds.)]. IPCC, Geneva, Switzerland.

Jankovská, V. \& Pokorný, P. (2008). Forest vegetation of the last full-glacial period in the Western Carpathians (Slovakia and Czech Republic). Preslia 80, 307-324.

Kolström, M., Vilén, T. \& Lindner, M. (2011). Climate Change Impacts and Adaptation in European Forests. EFI Policy Brief 6, Helsinki.

Konias, H. (1951). Lesní hospodářství: Zvyšování dřevní produkce a ozdravění lesů na Opočensku. Nakl. JSČZ, Praha.

Konšel, J. (1931). Stručný nástin tvorby a pěstění lesů v biologickém ponětí. Čs. Matice lesnická, Písek.

Konvička, M., Fric, Z. \& Beneš, J. (2006). Butterfly extinction in European states: Do socioeconomic conditions matter more than physical geography? Global Ecol. Biogeogr. 15(1), 82-92. DOI: 10.1111/j.1466-822X.2006.00188.x.

Koster, E. A. (1978). The eolian drift sands of the Veluwe, Central Netherlands: a physical geographical study. Thesis, University of Amsterdam.

Koster, E. A. (2010). Origin and development of Late Holocen drift sands: geomorphology and sediment attributes. In: Fanta J. \& Siepel H. (eds.), Inland drift sand landscapes. KNNV Publishing, Zeist.

Košulič, M. sen. (2010). Cesta k přirodě blizkému hospodářskému lesu. FSC-ČR, Brno.

Lafond, V. et al. (2014). Uneven-aged management options to promote forest resilince for climate change adaptations: effects of group selection and harvesting intensity. Annals For. Sci. 71, 173-186. DOI: 10.1007/s13595-013-0291-y.

Leuzinger, S. et al. (2005). Responses of deciduous forest trees to severe drought in Central Europe. Tree Physiol. 325, 641-650.

Lévesque, M. et al. (2013). Drought response of five conifer species under contrasting water availability suggests high vulnerability of Norway spruce and European larch. Global Change Biol. 19, 3184-3199. DOI: 10.1111/gcb.12268.

Lindenmayer, D. B., Franklin, J. F. \& Fischer, J. (2006). General management principles and a checklist of strategies to guide forest biodiversity conservation. Biol. Conserv 131(3), 433-445. DOI: 10.1016/j.biocon.2006.02.019.

Lindenmayer, D. B., Hulvey, K. B., Colyvan, M., Felton, A., Possingham, H., Steffen, W., Wilson, K., Youngentob, K. \& Gibbons, P. (2012). Avoiding bio-perversity from carbon sequestration solutions. Conserv. Letters 5, 28-36. DOI: 10.1111/j.1755-263X.2011.00213.x.

Lindner, M., Maroschek, M., Netherer, S., Kremer, A., Barbati, A., Garcia-Gonzalo, J., Seidl, R., Delzon, S., Corona, P., Kolström, M., Lexer, M. J. \& Marchetti, M. (2010). Climate change impacts, adaptive capacity, and vulnerability of European forest ecosystems. For. Ecol. Man. 259, 698-709. DOI:20.1016/j.foreco.2009.09.023.

Löhmus, A. \& Runnel, K. (2014). Ash dieback can rapidly eradicate isolated epiphyte populations in production forests: A case study. Biol. Conserv. 169, 185-188. DOI: 10.1016/j.biocon.23013.11.031.

Loo, J. A. (2009). Ecological impacts of non-indigenous invasive fungi as forest pathogens. Biol. Invasions 11, 81-96.

Ložek, V. (1973). Přiroda ve čtvrtohorách. Academia, Praha. 
Machar, I., Vlčková, V., Šálek, L., Pechanec, V., Nowak, A., Nowak, S., Plášek, V., Svajda, J., Opršal, Z. \& Topacoglu, O. (2019). Environmental Modelling of Forest Vegetation Zones as a Support Tool for Sustainable Management of Central European Spruce Forests. Journal of Landscape Ecology 11(3): 45-63.

Millenium Ecosystem Assessment (2005). Ecosystems and Human Wellbeing. Synthesis. Island Press, Washington.

Moldan, B. (ed.) (1993). Rizika změny klimatu a strategie jejich snižení. ČHMÚ, Praha.

Möller, A. (1922). Der Dauerwaldgedanke, sein Sinn und seine Bedeutung. Berlin.

Moning, C. \& Müller, J. (2009). Critical forest age thresholds for the diversity of lichens, molluscs and birds in beech (Fagus sylvatica) dominated forests. Ecol. Indicators. 9(5), 922-932. DOI: 10.1016/j.ecolind.2008.11.002.

Moser, B., Metslaid, M., Wasem, U. \& Wohlgemuth, T. (2015). Verjüngungspotenzial verschiedener Waldföhren- und Fichtenherkünfte bei variabler Trockenheit. Schweiz. Zeitschr. Forstwes. 166, 399-407.

Nabuurs, G.-J. (2019). Future scenarios of European forests. Journal of Landscape Ecology 11(3): 175-184.

Oliva, J. \& Stenlid, J. (2012). Understanding the role of sapwood loss and reaction zone formation on radial growth of Norway spruce (Picea abies) trees decayed by Heterobasidion annosum s.1. Forest Ecol. Man. 274, 201-209.

Ott, E., Lüscher, F., Frehner, M. \& Brang, P. (1991). Verjüngungsökologische Besonderheiten im Gebirgsfichtenwald in Vergleich zur Bergwaldstufe. Schweiz. Zeitschr. Forstwes. 142, 879-904.

Paillet, Y., Berges, L., Hiälten, J., Ódor, P., Avon, C., Bernhardt-Römermann M. et al. (2010). Biodiversity differences between managed and unmanaged forests: Meta-analysis of species richness in Europe. Conserv. Biol. 24(1), 101-112. DOI: 10.1111/J.1523-1739.2009.01399.x.

Perpeet, M. (2001). Naturnaher Waldbau - die Waldentwicklungstypen der Bundesforstverwaltung. Min. der Finanzen, Bonn.

Petř́k, P., Fanta, J. \& Petrtýl, M. (2015). It is time to change land use and landscape management in the Czech Republic. Ecos. Health Sustainab. 1(9), 1-6. DOI: 10.1890/15-0016.1.

Pokorný, P. (2013). Dějiny lesa. K poznání vztahů člověka a př́rodního prostředí. In: Bárta M. \& M. Kovár̆: Civilizace a dějiny. Historie světa pohledem dvaceti českých vědců. Academia, Praha, s. 401-426.

Pretel, J. (2009). Současný vývoj klimatu a jeho výhled. Ochrana přirody 64, 2-7.

Pretzsch, H. et al. (2015a). Long-term stand dynamics of managed spruce-fir-beech mountain forests in Central Europe: structure, productivity and regeneration success. Forestry 88, 407-428.

Pretzsch, H., del Río, M., Ammer, Ch., Avdagic, A., Barbeito, I., Bielak, K., Brazaitis, G., Coll, L. et al. (2015b). Growth and yield of mixed versus pure stands of Scots pine (Pinus sylvestris L.) and European beech (Fagus sylvatica L) analysed along a productivity gradient through Europe. Eur. J. Forest Res. 134, 927-947. DOI: 10.1007/s10342-15-0900-4.

Př́hoda, J. \& Lukášová, V. (eds.) (2014). Lesy střední a severní Moravy jsou v ohrožení. Les. práce 11, 5-9.

Putz, F. E. \& Redford, K. H. (2009). Dangers of carbon-based conservation. Global Envir. 
Change 19(4), 400-401. DOI:10.1016/j.gloenvcha.2009.07.005.

Remeš, J. Development and present state of close-to-nature silviculture. Journal of Landscape Ecology 11(3): 17-32.

Remund, J., von Arx, G., Gallien, L., Rebetez, M., Huber, B. \& Zimmermann, N. E. (2016). Klimawandel in der Schweiz-Entwicklung waldrelevanter Klimagrössen. In: Pluess A. R. et al. (eds.). Wald im Klimawandel - Grundlagen für Adaptationsstrategien. Haupt, Bern-Stuttgart-Wien, pp. 23-37.

Rothe, A., Köhling, C. \& Moritz, K. (1998). Waldbewirtschaftung und Grundwasserschutz Der aktuelle Kenntnisstand. AFZ/Der Wald 53, 291-295.

Rothe, A. \& Mellert, K. H. (2004). Effects of forest management on nitrate concentrations in seepage water of forests in southern Bavaria, Germany. Water Air Soil Pollution 156, 337-355.

Rubner, K. (1968). Grundlagen des naturnahen Waldbaus in Europa. Forstwiss. Cblt. 87, 8-36.

Scheidegger, C., Werth, S. et al. (2009). Conservation strategies for lichens: Insights from population biology. Fungal Biol. Reviews 23(3), 55-66. DOI: 10.1016/j.fbr.2009.10.003

Schelhaas, M.-J., Nabuurs, G.-J. \& Schuck, A. (2003). Natural disturbances in the European forests in the 19th and 20th centuries. Global Change Biol. 9(11), 1620-1633. DOI: 10.1046/j.1365-2486.2003.00684.x.

Stachová, J. (2019). Forests in the Czech public discourse. Journal of Landscape Ecology 11(3): 33-44.

Sturrock, R. N., Frankel, S. J., Brown, A. V., Hennon, P. E., Kliejunas, J. T., Lewis, K. J., Worrall, J. J. \& Woods, A. J. (2011). Climate change and forest diseases. Plant Pathol. 60, 133-149. DOI: 10.1111/j.1365-3059.2010.02406.x.

Virkkala, R., Heikkinen, R. K., Leikola, N. \& Luoto, M. (2008). Projected large-scale range reductions of northern-boreal land bird species due to climate change. Biol. Conserv. 141(5), 1343-1353. DOI: 10.1016/j.biocon.2008.03.007.

Vitasse, Y., Hoch, G., Randin, C. F., Lenz, A., Kollas, C. \& Körner, C. (2012). Tree recruitment of European tree species at their current upper elevation limits in the Swiss Alps. J. Biogeogr. 39(8), 1439-1449. DOI: 10.1111/j.1365-2699.2012.02697.x.

von Carlowitz, H. C. (1713). Sylvicultura Oeconomica oder Hauswirthliche Nachricht und Naturmässige Anweisung zur wilden Baum-Zucht. Braun, Leipzig.

von Teuffel, K. (1999). Waldentwicklungstypen in Baden-Württemberg. AFZ/Der Wald 54, 672-676.

von Teuffel, K. \& Krebs, M. (1999). Forsteinrichtung im Wandel. AFZ/Der Wald 54, 858-865.

Vor, T., Spellmann, H., Bolte, A. \& Ammer, Ch. (eds.) (2015). Potentiale und Risiken eingeführter Baumarten. Baumartenportraits mit naturschutzfachlicher Bewertung. Göttinger Forstwiss., B. 7. Uni-Vlg., Göttingen.

Wagner, S., Nocentini, S., Huth. F. \& Hoogstra-Klein, M. (2014). Forest management approaches for coping with uncertainty of climate change: Trade-offs in service provisioning and adaptability. Ecology and Society 10, art. 32. DOI: 10.575/ES-06213-190132.

Zimmermann, N. E. (2013). Future ranges in European tree species. In: Fitzgerald J. \& Lindner M. (eds.), Adapting to climate change in European forests - Results of the MOTIVE project. Pensoft Publishers, Sofia. 